\title{
Urban Area Entities in Affecting Regional Development: A Case Study for Mebidangro
}

\author{
Muhammad Taufiq ${ }^{1}$ \\ School of Architecture, Planning and Policy Development \\ Institut Teknologi Bandung, Bandung, Indonesia

\section{Benedictus Kombaitan} \\ School of Architecture, Planning and Policy Development \\ Institut Teknologi Bandung, Bandung, Indonesia \\ $\begin{array}{ll}\text { Artikel Masuk } & : \text { 7 Februari } 2019 \\ \text { Artikel Diterima } & : 12 \text { November } 2019 \\ \text { Tersedia Online } & : \text { 31 Desember } 2019\end{array}$
}

\begin{abstract}
How is an urban area influencing regional development? Urban area development policy with the primary purpose of driving its surrounding area development found a shift in meaning under the latest development. It initiates a complex relation between cities as network dots, which is not globally separable. This study aims to provide a theoretical analysis regarding its considerations and implications in practice through a study case of the Mebidangro urban area (Medan City-Binjai City-Deli Serdang District-Karo District) in North Sumatra Province, Indonesia. By using a content analysis method, the study evaluates the regional development policy. The result shows that Mebidangro urban area plays a role in influencing regional development through four entities: i.e., reducing income disparity, the centrality of productions and services, urbanization under the mobility context of labor and knowledge, and regional and international cooperation. The study also found that there is a tendency in which nowadays cities are not seen as a hierarchy. However, cooperation functions and its limits are global (world cities networks), not administrative or region. The fact supports an argument that the current area planning context is not only creating its surrounding area development but also as a part of the global city network. Mebidangro is one of the cases that illustrated this concept of operationalization practice. Through existing policy, this urban area was in such a way created to be able to become global city networks as a shifting of regional development planning paradigm from increasing surrounding area development to a region globally compete.
\end{abstract}

Keywords: global city network; Mebidangro; urban area; Indonesia

\section{Introduction}

Regional development involves a relation between various region interacting with each other. The interaction between these regions evolves in realizing regional growth with serve and support each other. Regional development driven by a city as growth center is a classical context interpreted through a domino effect, i.e., regional development one of

\footnotetext{
${ }^{1}$ Korespondensi Penulis: School of Architecture, Planning and Policy Development, Institut Teknologi Bandung, Indonesia Email: taufiqlangkat@gmail.com
} 
them is done through arrangement city center expected increasing regional development for its surrounding area, regarding economic, social and environmental development. If a city can drive regional growth for its surrounding area, so urban region perhaps able to influence its surrounding area with a higher level of ability. One of the efforts made for regional development is urban area planning policy, i.e., the metropolitan area is endeavored to be a driver for its surrounding area development, and be a way toward competitive advantages.

Clark, Harrison, \& Miguelez (2018) argues that the implication of cities role and function spatially (for a place) and socially (for people) continuously change and unpredictable. Cities drive economic growth through goods and services flows. They facilitate infrastructure for supporting the activities. However, city development does not only drives surrounding area development, and it is not hierarchical, due to shifting of central place theory on nowadays realities (Derudder \& Taylor, 2018), inviting other entities to be understood. This study evaluates urban area role in influencing regional development under the context.

One of the regional planning concentrations is about city centers in moving economic growth and regional development. The planning is done through arrangement growth area in a city. It operationalized through structure and pattern in regional spatial planning. Urban area regional planning concept is one of the study cases reflects that thought. It related to the network process between various areas driven by city centers close together and growing to be an urban area. Furthermore, Clark et al. (2018) states that crowded city, concentrated and connected is a key for increasing competitiveness and developing cohesion. How is an urban area influencing regional development? This study evaluates a regional development policy through urban area arrangement. This study aims to provide a theoretical analysis regarding its considerations and implications in practice through a study case of the Mebidangro urban area (Medan City-Binjai City-Deli Serdang District-Karo District).

Mebidangro is a regional development policy through arrangement four adjacent urban area, i.e., Medan City, Binjai City, Deli Serdang District, and Karo District in North Sumatra Province, Indonesia. The policy is one of the national strategic plans for regional development in Indonesia. One of its purposes is to be an internationally competitive region, and sustainable as national activity center in northern of Sumatra Island. The policy carried out leading to increasing productive national economic center and efficient, so that able to internationally compete particularly in sub-regional economic cooperation of Indonesia-Malaysia-Thailand growth triangle (IMT-GT), also growing urban activity center service accesses.

Previous studies have indicated a connection between one city and another in the context of the global city network (Hoyler \& Harrison, 2017; Khan, Brunner, \& Gibson, 2018; Neal, 2011). They argue that cities in the world become more open so that the boundaries of a city are no longer the boundaries of the country, but the extent to which the city serves the cities that interact with it. It is of interest to know what their considerations and implications are in practice, through a review of cities in the form of urban areas. Research still lacks understanding of how urban areas affect the development of surrounding areas and regions outside their countries, especially in archipelagic countries like Indonesia. This article offers theoretical and empirical contributions to the field of urban planning. Theoretically, this proposes the assumption that urban areas, especially in the archipelagic country in Indonesia, are moving towards globally open cities, but in ways that might be different from others. Empirically, the sustainability of the Mebidangro urban area is useful for stakeholders in formulating urban planning policies.

Generally, this study agree that cities composition as a hierarchy. Bigger cities (city) serve smaller cities (town) up to rural level (village), as a cooperation form need each other. 
The cooperation provides a cities system in the way of k1 (market), k2 (transportation), and $\mathrm{k} 7$ (administration services). The concept, at least, is a theoretical approach clarify how cities connected through the three of cities system modes. The most significant driving factor is located in the cities characterized by the largest population and can be hierarchically reviewed (central place theory). This view acceptable with some assumptions that all of the region on one stretch or in a close together distance.

Central place theory is a formal description from generically cities process (Derudder \& Taylor, 2018). Indeed, the method still prevalent accepted for explaining how certain cities system plays a role in regional development. On its development, however, for cities having innovation, production network, distribution, and consumption between regions at a broader level can no longer be assumed as a hierarchy (Clark et al., 2018). Christaller (1966) understood that relation between the cities regions like hexagons bordering each other. It interprets that its regional development process tends to border by the hexagons proximity without considering another area outside of the hexagonal border which is also influenced by the region.

Nowadays, urban development provides an influence in regional development not only for their surrounding areas but also for regions outside of their territorial. They take place through global interaction. The system tends to shapes functional cooperation, and the limit is global, not administration or regional (world cities network). In other words, cities have a potential to be regional development drivers, not only for surrounding areas but also for regions outside of their administration or their hexagons.

In a regional development context, cities expand to increase their capacity through the industrial and service patterns, not only focus on center-periphery relation but also toward world cities network (Liu \& Derudder, 2012; Martinus \& Sigler, 2017; Rozenblat, Zaidi, \& Bellwald, 2017). The discourse, at least, experiencing development from city evolution in city planning (Geddes, 1915), world cities (Hall, 1966), and global cities (Sassen, 1991). Furthermore, we might understand this view context with likens city as "regional node (Geddes, 1915), national (Hall, 1966), dan global (Sassen, 1991)" (Hoyler \& Harrison, 2017). Neal (2011) argues that there are four theoretical, and empirical city evolution: i.e., as a central place, metropolitan dominance, mercantile, new economy, and globalization. It leads to more open cities in the world. The occurred globalization tends due to the urban industry globalization, and innovation (Khan et al., 2018).

Cities innovating through entrepreneurship activities, and corporations be the drivers for this process. City and region not only place for this process occurred but also as the primary mechanism (Florida, Adler, \& Mellander, 2017). The process involves an urban network not only in proximity but also globally. They shape the global cities network (Martinus \& Sigler, 2017; Taylor, Derudder, Faulconbridge, Hoyler, \& Ni, 2014). The phenomenon tends to obscure city characteristic having a hierarchy with cities in the surrounding area (Parnreiter, 2014). Furthermore, Parnreiter (2014) delivers the critics regarding this discourse, that is a little who observe the processes of its formation, authors more often review its description and measure the cities system. Urban area planning policy in regional planning providing on this article is one of the cases reviewing the network formation process.

Recent studies have indicated that Indonesia's urban areas contribute to the development of the surrounding area. Jabodetabek metropolitan area (Jakarta, Bogor, Depok, Tangerang, and Bekasi) is driven by the role of the private sector in the fulfillment of public facilities and jobs (Firman \& Fahmi, 2017). In Kartamantul (Yogyakarta, Sleman, and Bantul), a collaborative collaboration between regional governments is carried out through cross-border infrastructure development in dealing with the expansion of urbanization (Hudalah, Firman, \& Woltjer, 2014). Cooperation between regions in Greater Bandung (Cimahi, Bandung City, Bandung Regency, West Bandung, and Sumedang) carries 
out the planning of the transportation system to advance the development of the region (Talitha \& Hudalah, 2014). Besides these urban areas, Indonesia has Mebidangro. This research focuses on understanding the urban areas presented by Mebidangro.

\section{Method}

This study uses a qualitative content analysis method for studying data (Mayring, 2014). It collects and analyzes several text contents (Neuman, 2014). All data used for this review are secondary data. The analysis is done by interpreting the meaning of the reading source and presenting it through theoretical conclusions. The article evaluates theories such as urban areas, central place, and global city and their practice on the empirical situation of mebidangro urban areas. Data sourced from journals, government regulations, internet news, and other research sources that support it. Mayring (2014) argues that a qualitative content analysis shortens a material into short texts that can be managed to develop categories in stages from several materials. This research categorizes what entities that an urban area has in contributing to the development of both surrounding areas and global context. No doubt, the author's meaning will affect the results of the analysis. However, this is useful for a broader sense of understanding the impact of urban expansion.

\section{Result and Discussion}

\section{Regional Development through the Urban Area}

An urban area is a form in regional development. The operationalization involves various cities bound in a region for driving economic growth its surrounding areas. In the global era, McCann \& Acs (2011) argues that multinational companies play an essential role in connecting an urban area globally, in other hands, center-periphery relation eventually drives national economic. The metropolitan area has the potential to participate in a global city network. Economic side tendency, in this case, is very thick due to this can not be realized if the business sector does not dominate it.

Urban area applies an advance producer strategy in regional development, it provides services for companies operating in different sector (Jacobs, Koster, \& Hall, 2011), build up spatial development pattern as a driving force, multi-location companies develop their intra-companies network internationally through two pillars: i.e., knowledge economy, and high technology company (Lüthi, Thierstein, \& Goebel, 2010). The urban area provides infrastructure for goods and services flow such as transportation (Gerritse \& Arribas-Bel, 2018), office space (Taylor, 2010), accommodation, and supporting facilities.

The discussion is interesting, about space functionally exchange, i.e., a shift in meaning "move away from simple core-periphery model" (Roy, 2009), hierarchical and networked. Regional development through the urban area has a potential to develop a growth space on an international scale. The context tends to review regional development not only influencing inter but also intra-region. Such as delivered by Rodríguez-Pose (2008) argue that urban area concept application as a policy has important implications for implementation of development strategy, regarding its change from sectoral to a regional approach, leads to a much bigger plan, and innovation diversity. The concept at least desires a more complex planning formulation. Handling involves cooperation between various stakeholders such as the government, the business world, and society. However, it seems still lacks understanding of how developing countries prepare their urban areas to adapt fo global developments and how these cities play a role in increasing regional development both internally and externally. This research moves in that direction. 
In developing countries, spatial inequality leads to activity grouping, such as manufacture activity, creating work and attracting population from other regions, spatial disparity tends to increase along with development and economic growth on a specific location and sector overgrowing while the others left behind (Venables, 2005). Therefore, the state intervenes in regional planning acceleration through urban, regional planning policy. It tends to connect central places in an extensive national network (Brenner, 1997), at least to realize a more efficient city structure. Its implication did through urban area arrangement. Metropolitan area 'armed' with infrastructures and growth locations. The influence embedded not only inter but also intraregional.

The urban area is a spatial economic key for a nation (Parr, 2005). A metropolitan area drives regional development through city-region interactions, trading, commuter, capital movements, resources, knowledge, and technology. The efforts are made for realizing spatial productivity, through urban area arrangement. Furthermore, Gerritse \& Arribas-Bel (2018) delivers that infrastructure can play a role in resulting productivity in municipal level, urban population moves during infrastructure changes, it makes cities in the region more productive. In the contemporary globalization context, the phenomenon involves physical and relational asset systems, and full of synergies lead to the need for an understanding to deal with increasing inequality between regions (Scott \& Storper, 2003). On further discussion, we will evaluate this through a case study, i.e., Mebidangro urban area, and describe the entities this area in influencing regional development.

\section{Mebidangro, A Regional Development Policy through Urban Area Arrangement}

As already introduced on the previous discussion that Mebidangro is one of the Indonesia national policies in regional development, particularly for the northern region of Sumatra Island in western Indonesia (see Figure 1). The policy is an effort for regional development acceleration and orderly arrangement of the regional development process. It involves development for 52 sub-districts such as 21 sub-districts in Medan City (Kota Medan), five sub-districts in Binjai City (Kota Binjai), 22 sub-districts in Deli Serdang District (Kabupaten Deli Serdang), and four sub-districts in Karo District (Kabupaten Karo). Mebidang has an area $2.719 \mathrm{~km}^{2}\left(1049,812 \mathrm{mil}^{2}\right)$ and with about five million people. Mebidangro arrangement is made through spatial planning such as space structure, space pattern and strategic steps (Ministry of Public Work and Spatial Planning, 2014a).

Mebidangro space structure involves main city planning and its around cities as supporting cities. The concept leads to monocentric city development, i.e., there is the main city node in the middle of lower level cities. The main city (Medan) provides services for organizing regional, national and international scale activities. It has the most dominant influence on goods flows, services, trading, resources, capital movements, knowledge, and technology. Cities around the main city serve as movement balancer for the main city. Various infrastructure facilities were built to realize this plan, such as built up or rearrangement existing facilities. The infrastructures such as port, airport, railroad network, highway, primary and secondary arterial road, primary collector road, and development center bases (monocentric in Medan) (see Figure 2). On the other hands, the planning concern for settlement center system, transportation network (road, river and crossing, railroad system, sea and air transportation), water resources, urban utilities (provision of drinking water systems, drainage and wastewater networks, waste management), energy networks (oil pipe and earth gas, power plant, electric power transmission), and telecommunications. 


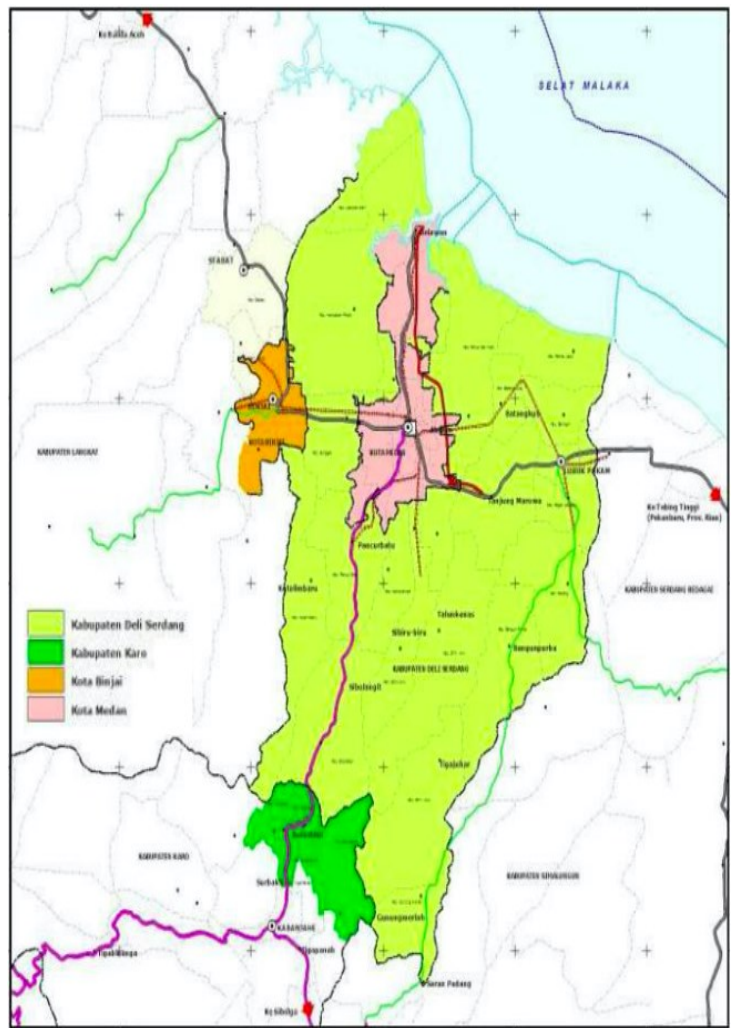

Source: Ministry of Public Work and Spatial Planning, $2014 b$

Figure 1. Map of Mebidangro

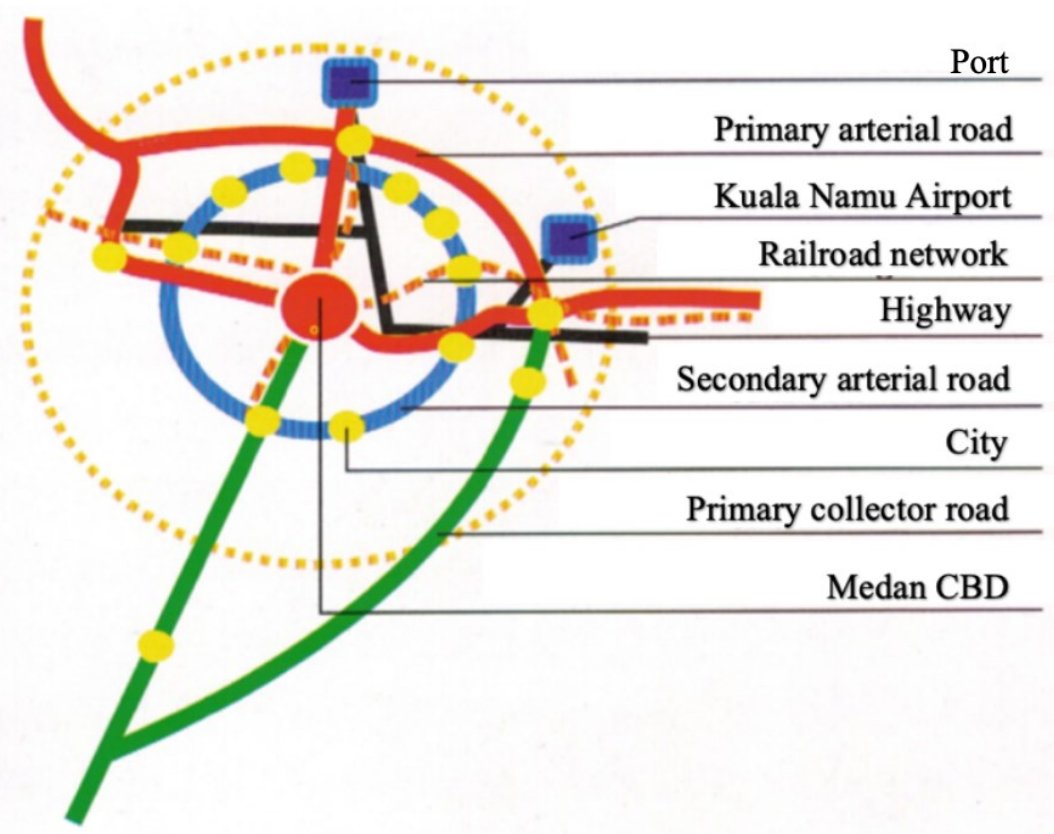

Source: Ministry of Public Work and Spatial Planning, $2014 a$

Figure 2. The Concept of Space Structure and Infrastructure Support of Mebidangro 
Mebidangro space pattern tends to prioritize optimization of protected and cultivation area utilization based on carrying capacity (see Figure 3). Its space pattern involves the arrangement of the various zone such as existing built-up land, urban planning, semi-urban planning, forest cultivation, and conservation. Mebidangro strategic plans involve several short-term policies such as (1) Belawan-Kuala Namu national economic corridor development; (2) service centers development for the new city; (3) revitalization of Medan old city center, and Tembakau Deli; (4) development and stabilization of Mebidangro green corridor; and (5) development of Mebidangro strategic access.

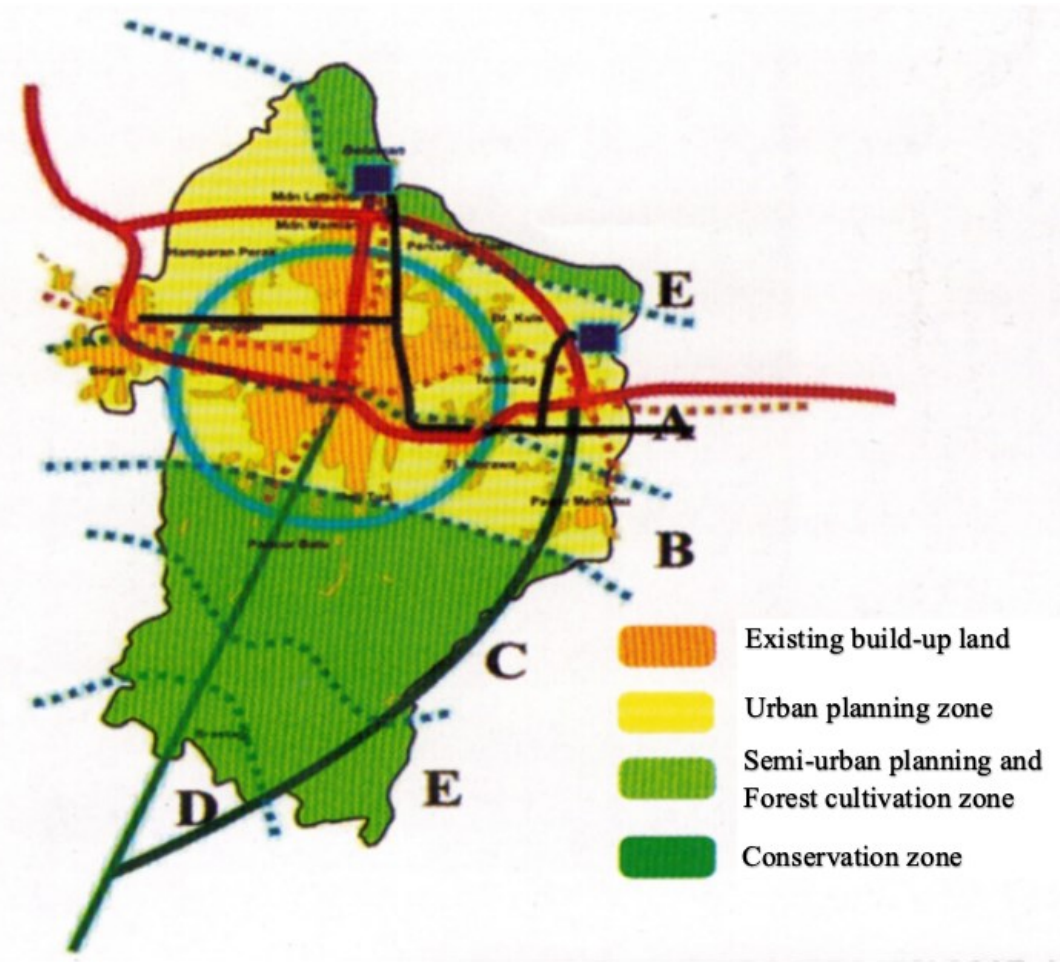

Source: Ministry of Public Work and Spatial Planning, 2014 a

Figure 3. The Concept of Mebidangro Space Pattern

Mebidangro has a broad influences in regional development. The planning conducted tends to prepare the urban region to play a role globally. With its strategic position, Mebidangro potential to be one of the global cities networks. The following entities as a form of its influence in influencing regional development.

\section{Reducing Income Disparity}

Mebidangro is one of the national strategic region aiming to reduce income disparity so that every area have better competitiveness in the economy. Economic growth in Mebidangro influences reducing income disparity level. The present of economic scale is the most important to support development aspects in developing countries. However, the occurred trends are income disparity due to an uneven regional growth condition. It as delivered by Venables (2005) due to economic growth rapidly develop only in a particular location or sector, while others left behind. Mebidangro arrangement tends to avoid growth focused only on a specific area with left behind its surrounding areas. It makes the surrounding cities (supporting cities) of the main city play a role as the balancer. It is added 
again with a mutual complementary infrastructure between the main and supporting city. The bases of the economic center which generally located in Medan can not stand-alone due to its infrastructure supported by surrounding cities such as Belawan Port (not in the city center) and Kuala Namu Airport in Deli Serdang District.

Some criticism comes from Dewanto, Rujiman., \& Suriadi (2014) concluding that economic growth and income disparity in Mebidangro (period of 2004-2011) have a negative influence on the poverty level. Although economic growth able to reduce poverty, however, income disparity be an obstacle or diminish economic growth effectivity in poverty alleviation. Economic growth in Mebidangro during 2004-2001, not pro-poverty (anti-poor). At least, the data is supported by the Central Bureau of Statistics presenting North Sumatra Province Gini ratio which is increasing from $2000(0,272)$, where the last Gini ratio is 0,319, but its classification still on low inequality level (Central Bureau of Statistics of North Sumatra, 2017). It is hard to assume that Mebidangro planning can indeed reduce income disparity, at least it has provided a broader space in cities growth so that can more rapidly develop and increasing each area income. The implication is although Mebidangro planning directed for the formation of urban area in monocentric form, however with the development of supporting cities, there is a chance for the creation of polycentric urban area form. It is backed with existing transportation infrastructure located out of the main city and the high enough of city development such as Deli Serdang area with its Kuala Namu Airport. It is in line with stated by Taylor, Evans, \& Pain (2008), that traditional cities areas centered on a city center are replacing by a more complex polycentric order.

\section{Centrality of Productions and Services}

The urban area planning tends related to the process of innovation, production network, distribution, and consumption between areas (Clark et al., 2018). Mebidangro has a capability in running national and international scale activities, and as an economic driving force with qualified facilities in increasing industry, service and trade sectors. Putra, Giyarsih, \& Kurniawan (2016) argues that Mebidangro has two leading sectors such as specialization on primary sector and diversification from various sectors with the highest hierarchy in Percut Sei Tuan Sub-District. In other hands, there are Medan Industrial Zone (Kawasan Industri Medan/ KIM), and Medan Star Industrial Estate in Deli Serdang which both of them be one of the essential national objects and office spaces in Mebidangro metropolitan region facilitating productions and services. On the outside of Mebidangro, there are Sei Mangke Special Economic Zone (Kawasan Ekonomi Khusus/KEK) combined with Kuala Tanjung Port connected through railway over $30 \mathrm{~km}$.

Mebidangro facilitates production and service flows. It has logistic connectivity infrastructure such as transportation for natural and human resources supporting economic growth. For logistic effectivity, there are infrastructures such as Balmera Highway connecting Medan-Kuala Namu (international airport)-Tebing Tinggi Railway connecting Medan-Lubuk Pakam-Tanjung Balai-Kuala Namu (international airport)-Belawan (international port)-Binjai. The infrastructure developments is an effort in connecting Mebidangro towards the international world. It has potential creates central flow connecting comparative connectivity in global cities network, where the connectivity dominantly is driven by the company, services, productions, and all entrepreneurs involved (Derudder \& Taylor, 2018).

\section{Urbanization under Mobility Context of Labor and Knowledge}

Urbanization can not be circumvented for urban area. Urbanization effected for regional development on providing labour supporting industries of trading and service. 
Mebidangro population growth in last twenty years is $30,95 \%$, and it is preached that in 2029 will reach 5.5 million people. The development of the Mebidangro urban area has a potential for increased mobility of labor and knowledge. The global company conducting the region automatically moves the workforce, innovation, and knowledge. However, on other hands, the regional planning faces a condition "opens city potential for regional revitalization, while at the same time deal with the challenge in line with city changes and fix worst effect of urbanization (Clark et al., 2018). The growth rate in Mebidangro impact on the people urbanization towards the area. One of the negative results is the spread of slum areas. Director General of Cipta Karya, Ministry of Public Works delivered that from 171 slum area handled by the ministry, there are five of the worst slum area in the country, one of them is Belawan, North Sumatra (Ariyanti, 2013; Detik, 2013).

\section{Regional and International Cooperation}

City interconnection and network raised from capital flows, workforce, and knowledge is embedded in the process, and also in the policy model moving between cities in an attempt for getting a more significant part of economic benefit (innovation, production, distribution, and consumption) (Clark et al., 2018). There is a tendency that knowledge concentrating on an area lead regional development process of origin place declining due to 'leakage' (Friedmann \& Alonso, 1975). The most likely occurred in satellite city, town, and suburb. Human resources from periphery many leaked to an advanced region. In this case, the human resources in Mebidangro which come from the surrounding area do not return to their hometown (critic for development from above).

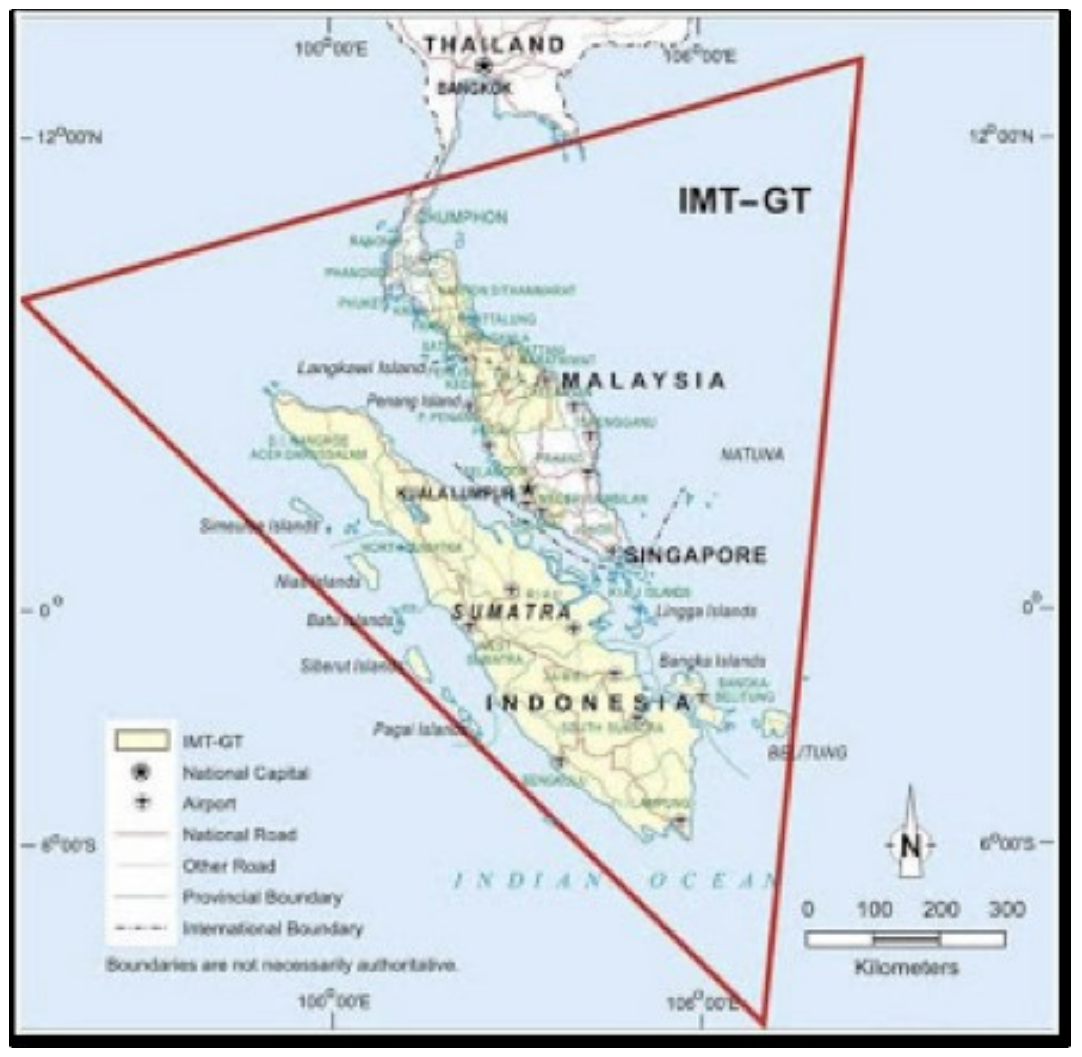

Source: Ministry of Public Work and Spatial Planning, $2014 \mathrm{~b}$

Figure 4. International Cooperation of IMT-GT 
Regional cooperation in the form of economic activity has been significantly running between cities in Mebidangro and between Mebidangro Urban Area and surrounding area such as Langkat District, Aceh Tamiang District, Dairi District, Simalungun District, Samosir District, and Serdang Bedagai District. Capital flows, goods and services are increasing. It marked by built up of Balmera Highway connecting existing economic area nodes for fulfilling and deciphering traffic density caused by the process.

Mebidangro international cooperation makes the metropolitan area be part of global cities networks. Mebidangro influences the Indonesia-Malaysia-Thailand Growth Triangle (IMT-GT) (see Figure 4). It together with a Mebidangro arrangement for increasing regional development. Its implementation done through transportation needs fulfillment between various region both nationally and internationally such as international airport, international port, road, and land transportation system. It also is done through optimizing region around Malaka Strait as trade and international mobility routes driven by Belawan and Sei Mangkar port. In the other hands, there is a significant investment chance for developing Semenanjung Malaka Zone to increase IMT-GT progress. For support primer scale infrastructure of collection center, there is Kuala Namu International Airport. Mebidangro plays a role for economic activity on five IM-GTconnectivity corridors such as Songkhla-Penang-Medan, Malaka Strait, Banda Aceh-Medan-Dumai-Palembang, MelakaDumai, and Ranong-Phuket-Aceh (Ministry of Foreign Affairs, 2010).

Economic growth through international cooperation tends to create global cities network. As delivered by Scott that particular urban regions in some less-developed countries eventually will be considered as dynamic nodes for mosaics that develop from global city-region (Scott, 2001). Economic growth in Mebidangro will develop for flowing capital rate internationally. However, the efforts in investment forms and large-scale projects are needed to be implemented.

There is a tendency that various policies for Mebidangro arrangement make this urban region become more play a role as a network than a hierarchy (criticism for central place theory). The efforts tend not only centralized for a city but also spread to various cities. Placement of the infrastructures makes it happen. They are spreadly placed in various cities. It makes cities development in Mebidangro rapidly growth and not collectively. The spread of economic area development and infrastructure impact on these cities grew to be a polycentric form. It means that their development no longer referring to the main city, but instead relates to their each cities destination mobility of production flow, globally. It is because the process uses infrastructures in each area, which of course not located in the main city. Regarding growth rate in supporting cities driven by the main city, there is a phenomenon that although goods and services flow connected to the main city, however, no one ensures that it happened. There is a tendency that the supporting cities through the arrangement policies become non-hierarchical with the main city, but more related with abroad cities globally on the context of their large-scale goods and services flows. The context raises a presumption that cities in the scope of Mebidangro will tend to shape network form than hierarchy.

\section{Conclusion}

The urban area plays a role in influencing regional development through several entities such as reducing income disparity, centrality of productions and services, urbanization under mobility context of labor and knowledge, and regional and international cooperation. The infrastructures within Mebidangro bring this urban area to drive regional development not only for each city and their surrounding area but also for global development. Labor and knowledge mobilization make it happen. Although it is monocentric in inter-regional (hierarchical) regional development, however, Mebidangro 
also plays a role in forming intra-regional influences. In this phenomenon, there is a tendency that cities are not viewed as a hierarchy, but function cooperation, and its limit is a global, not administrative area or regional (world cities networks). The notion initiates urban area planning context which is not only creating regional development for its surrounding area but also global cities networks. Mebidangro is one of the study cases operating the concept.

Furthermore, Meijers (2007) argues that ideas on network models of spatial organizations arise as a response to refute the central place theory. One of its developments is the appearance of global cities concepts (Parnell \& Robinson, 2012; Robinson, 2002; Smith \& Timberlake, 2001). By the existing policies, the urban region is created to be a part of global cities network, a paradigm shift of regional development from increasing surrounding areas to be a region which can compete globally. The phenomenon brings up a notion that Mebidangro urban area has potential in globally regional planning for global development.

This research provides a theoretical insight into state policies that support the global connection of cities, especially in the Indonesian context. The result supports the idea that future projections for the development of cities in the world tend to have global nuances. Nevertheless, not only that, this global connectivity itself is not open through the unilateral policies of the countries concerned, but is supported by cooperation between countries through proper interconnectivity regulations.

\section{References}

Ariyanti, F. (2013). Yuk Intip, 5 kawasan kumuh terparah di Indonesia. Retrieved from https://www.liputan6.com/bisnis/read/687844/yuk-intip-5-kawasan-kumuh-terparah-di-indonesia.

Brenner, N. (1997). State territorial restructuring and the production of spatial scale. Political Geography, 16(4), 273-306. doi:10.1016/s0962-6298(96)00003-0.

Central Bureau of Statistics of North Sumatra. (2017). Gini ratio Sumatera Utara menurut kabupaten/kota, 2000-2016. $\quad$ Retrieved December $12, \quad$ 2018, from https://sumut.bps.go.id/statictable/2017/02/14/598/gini-ratio-sumatera-utara-menurut-kabupatenkota-2000-2016.html.

Christaller, W. (1966). Central places in Southern Germany. New Jersey: Prentice-Hall, Englewood Cliffs.

Clark, J., Harrison, J., \& Miguelez, E. (2018). Connecting cities, revitalizing regions: the centrality of cities to regional development. Regional Studies, 52(8), 1025-1028. doi:10.1080/00343404.2018.1453691.

Derudder, B., \& Taylor, P. J. (2018). Central flow theory: comparative connectivities in the world-city network. Regional Studies, 52(8), 1029-1040. doi:10.1080/00343404.2017.1330538.

Detik. (2013). Ini penampakan 5 kawasan paling kumuh di Indonesia. Retrieved October 16, 2018, from https://finance.detik.com/berita-ekonomi-bisnis/d-2355224/ini-penampakan-5-kawasan-paling-kumuhdi-indonesia.

Dewanto, P., Rujiman., \& Suriadi, A. (2014). Analisis pengaruh pertumbuhan ekonomi dan ketimpangan pendapatan terhadap pengentasan kemiskinan di Kawasan Mebidangro. Jurnal Ekonom, 173), 138-150.

Firman, T., \& Fahmi, F. Z. (2017). The privatization of metropolitan Jakarta's (Jabodetabek) urban fringes: The early stages of "post-suburbanization" in Indonesia. Journal of the American Planning Association, 83(1), 68-79. doi:10.1080/01944363.2016.1249010.

Florida, R., Adler, P., \& Mellander, C. (2017). The city as innovation machine. Regional Studies, 51(1), 86-96. doi:10.1080/00343404.2016.1255324.

Friedmann, J., \& Alonso, W. (1975). Regional Development and Planning: A Reader. Massachusetts: The M.I.T. Press.

Geddes, P. (1915). Cities in evolution: an introduction to the town planning movement and to the study of civics (2015 Editi). London: Williams \& Norgate. 


\section{Urban Area Entities in Affecting Regional Development: A Case Study for Mebidangro}

Gerritse, M., \& Arribas-Bel, D. (2018). Concrete agglomeration benefits: do roads improve urban connections or just attract more people? Regional Studies, 52(8), 1134-1149. doi:10.1080/00343404.2017.1369023.

Hall, P. G. (1966). The world cities. London: Weidenfeld and Nicolson.

Hoyler, M., \& Harrison, J. (2017). Global cities research and urban theory making. Environment and Planning A, 49(12), 2853-2858. doi:10.1177/0308518x17735405.

Hudalah, D., Firman, T., \& Woltjer, J. (2014). Cultural cooperation, institution building and metropolitan governance in decentralizing Indonesia. International Journal of Urban and Regional Research, 38(6), 2217-2234. doi:10.1111/1468-2427.12096.

Jacobs, W., Koster, H., \& Hall, P. (2011). The location and global network structure of maritime advanced producer services. Urban Studies, 48(13), 2749-2769. doi:10.1177/0042098010391294.

Khan, S., Brunner, J., \& Gibson, D. (2018). Changing the mindset to encourage innovation in resolving problems in the built environment: Exploring the role of online gaming platforms to deliver collaborative learning and teaching. Journal of Regional and City Planning, 29(2), 83-97. doi:10.5614/jrcp.2018.29.2.1.

Liu, X., \& Derudder, B. (2012). Two-mode networks and the interlocking world city network model: a reply to neal. Geographical Analysis, 44(2), 171-173. doi:10.1111/j.1538-4632.2012.00844.x.

Lüthi, S., Thierstein, A., \& Goebel, V. (2010). Intra-firm and extra-firm linkages in the knowledge economy: the case of the emerging mega-city region of Munich. Global Networks, 19(1), 114-137. doi:10.1111/j.14710374.2010.00277.x.

Martinus, K., \& Sigler, T. J. (2017). Global city clusters: theorizing spatial and non-spatial proximity in interurban firm networks. Regional Studies, 1-13. doi:10.1080/00343404.2017.1314457.

Mayring, P. (2014). Qualitative content analysis: theoretical foundation, basic procedures and software solution. Gesis: Leibniz Institut für Sozialwissenschaften. Klagenfurt: Erstveröffentlichung. doi:10.4135/9781446282243.n12.

McCann, P., \& Acs, Z. J. (2011). Globalization: Countries, cities and multinationals. Regional Studies, 45(1), 1732. doi:10.1080/00343404.2010.505915.

Meijers, E. (2007). From central place to network model: Theory and evidence of a paradigm change. Tijdschrift Voor Economische En Sociale Geografie, 98(2), 245-259. doi:10.1111/j.1467-9663.2007.00394.x.

Ministry of Foreign Affairs. (2010). Indonesia-Malaysia-Thailand growth triangle (IMT-GT). Retrieved from https://www.kemlu.go.id/id/kebijakan/kerjasama-regional/Pages/IMT-GT.aspx.

Ministry of Public Work and Spatial Planning. (2014a). Metropolitan Mebidangro visi 2017. Jakarta: Ministry of Public Work and Spatial Planning.

Ministry of Public Work and Spatial Planning. (2014b). Rencana tata ruang kawasan Medan, Binjai, Deli Serdang, Karo. Jakarta: Ministry of Public Work and Spatial Planning.

Neal, Z. P. (2011). From central places to network bases: a transition in the U.S urban hierarchy, 1900-2000. City \& Community, 10(1), 49-75. doi:10.1111/j.1540-6040.2010.01340.x.

Neuman, W. (2014). Social research methods: Qualitative and quantitative approaches. Essex: Pearson.

Parnell, S., \& Robinson, J. (2012). (Re)theorizing cities from the global south: Looking beyond neoliberalism. Urban Geography, 33(4), 593-617. doi:10.2747/0272-3638.33.4.593.

Parnreiter, C. (2014). Network or hierarchical relations? a plea for redirecting attention to the control functions of global cities. Tijdschrift Voor Economische En Sociale Geografie, 105(4), 398-411. doi:10.1111/tesg.12095.

Parr, J. (2005). Perspectives on the city-region. Regional Studies, 39(5), 555-566. doi:10.1080/00343400500151798.

Putra, M., Giyarsih, S. R., \& Kurniawan, A. (2016). Kajian sektor unggulan dan fungsi wilayah pada kawasan strategis nasional perkotaan Mebidangro. Universitas Gadjah Mada.

Robinson, J. (2002). Global and world cities: a view from off the map. International Journal of Urban and Regional Research, 26(3), 531-554. doi:10.1111/1468-2427.00397.

Rodríguez-Pose, A. (2008). The rise of the "city-region" concept and its development policy implications. European Planning Studies, 168), 1025-1046. doi:10.1080/09654310802315567.

Roy, A. (2009). The 21st-century metropolis: New geographies of theory. Regional Studies, 43(6), 819-830. 
doi:10.1080/00343400701809665.

Rozenblat, C., Zaidi, F., \& Bellwald, A. (2017). The multipolar regionalization of cities in multinational firms' networks. Global Networks, 172), 171-194. doi:10.1111/glob.12130.

Sassen, S. (1991). The global city: New York, London, Tokyo. New Jersey: Princeton University Press.

Scott, A. J. (2001). Globalization and the rise of city-regions. European Planning Studies, 97), 813-826. doi:10.1080/09654310120079788.

Scott, A., \& Storper, M. (2003). Regions, globalization, development. Regional Studies, 376), 579-593. doi:10.1080/0034340032000108697a.

Smith, D. A., \& Timberlake, M. F. (2001). World city networks and hierarchies, 1977-1997. American Behavioral Scientist, 44(10), 1656-1678. doi:10.1177/00027640121958104.

Talitha, T., \& Hudalah, D. (2014). Model kerjasama antar daerah dalam perencanaan sistem transportasi wilayah. Tata Loka, 16(4), 194-208. doi:10.14710/tataloka.16.4.194-208.

Taylor, P. J. (2010). Specification of the world city network. Geographical Analysis, 33(2), 181-194. doi:10.1111/j.1538-4632.2001.tb00443.x.

Taylor, P. J., Derudder, B., Faulconbridge, J., Hoyler, M., \& Ni, P. (2014). Advanced producer service firms as strategic networks, global cities as strategic places. Economic Geography, 90(3), 267-291. doi:10.1111/ecge.12040.

Taylor, P. J., Evans, D. M., \& Pain, K. (2008). Application of the interlocking network model to mega-cityregions: Measuring polycentricity within and beyond city-regions. Regional Studies, 42(8), 1079-1093. doi:10.1080/00343400701874214.

Venables, A. J. (2005). Spatial disparities in developing countries: cities, regions, and international trade. Journal of Economic Geograph, 5(1), 3-21. doi:10.1093/jnlecg/lbh051. 